DOI https://doi.org/10.30525/978-9934-26-000-1-8

\title{
РЕПРЕЗЕНТАЦІЯ ВОСННОЇ ДІЙСНОСТІ АВТОРОМ-УЧАСНИКОМ ПОДІЙ (НА МАТЕРІАЛІ РОМАНУ В. АНАНЬСВА «СЛІДИ НА ДОРОЗІ»)
}

\author{
Червінчук А. О. \\ старший викладач кафедри журналістики, \\ реклами та медіакомунікацій \\ Одеський національний університет імені I. I. Мечникова \\ м. Одеса, Україна
}

Війна в Україні стала об'єктом рецепції журналістів, письменників та безпосередніх учасників бойових дій, волонтерів. Статус комуніканта значним чином впливає на специфіку репрезентації воєнної дійсності, адже автор - той, хто моделює воєнний світ та героїв, які перебували в умовах збройного конфлікту. Так, цей статус визначає позицію, вектор та спосіб репрезентації воєнної дійсності: автор-спостерігач за подіями (журналіст, некомбатант) та автор-учасник подій (військовий, комбатант) [2, с. 224]. У своєму дослідженні вважаємо за необхідне підкреслити, що осмислення війни та передача бойового досвіду безпосередніми учасниками бойових дій на відміну від журналістів «авторів-спостерігачів за подіями (авторів-некомбатантів), не регламентується/не обмежується журналістськими стандартами, або в окремих випадках правилами подачі інформації, а тому у їхніх збірках більше «волі» для автора, що зумовлено їх позицією - автора-учасника подій (автора-комбатанта)» [2, с. 224].

Особливої уваги потребують документальні збірки, що експлікують досвід учасників бойових дій. Як зауважила М. Коцюбинська, «фіксація події - чи то зовнішньої, реальної, внутрішньої (емоції, суб'єктивні враження і реакції, психологічні самонотатки, світ індивідуальних переживань та самоаналізу) - важлива як акт пізнання» [3, с. 21].

Автор-учасник, зафіксувавши події безпосередньо «на полі бою», чи осмисливши пережитий досвід після повернення з війни, сконструював уявлення про дійсність, в якій він перебував; репрезентований автором світ - воєнна «реальність», особлива атмосфера якої вмістила в себе не тільки перебіг бойових дій, але й - емоції та реакції учасників. У збірках такого типу авторами відображені історії про пережитий воєнний досвід; події на Сході України автори-учасники сприймають як персональну війну.

Підкреслимо, що для збірок характерний наративний спосіб організації воєнної історії: спогади та свідчення учасників подій «жорстко сконцентровані на конкретних хронологічних межах» [4, с. 47]. Водно- 
час для історій такого типу характерна суб'єктивність: автори не всюдисущі, обмежені у часопросторі [5, с. 261], тому здатні фіксувати та передавати події, що відбулися «тут і зараз»; описавши факти, автори вдаються до демонстрації власних переживань, поглядів, оцінок пережитого, за допомогою чого сформувались та чітко виразились авторські уявлення про війну. Окрім цього, увага зосереджена на внутрішньому світі розповідачів: виклад історії характеризується високим рівнем емоційності, деталізуються та конкретизуються пережиті ними події; яскраво виражений емоційний стан у кульмінаційні моменти, аби в аудиторії не виникало потреби самостійно заповнювати так звані «порожні місця» (за Р. Інгарденом).

Принципово важливим для нашого дослідження є те, що автором роману «Сліди на дорозі» став професійний військовослужбовець (пройшов навчання та службу у десантних військах до початку воєнних дій). Пережитий досвід - участь у бойових діях - осмислювався В. Ананьєвим після повернення 3 війни, що суттєво відобразилось на формально-змістовій організації твору. Події автором переосмислені, а тому виклад характеризується не емоційністю, а раціональністю. До уваги аудиторії представлено персональну історію учасника бойових дій на Сході України: не у вигляді записок із фронту, щоденникових записів, а - у вигляді цілісного тексту. У романі простежуються три конкретні періоди 3 життя (розповідь характеризуються лінійним викладом): спогади про дитинство та навчання в школі, перебування в армії, участь у російсько-українській війні. Військове життя (в тому числі й армійське життя в десантних військах) та навколишня дійсність критично оцінюються автором.

Автор чітко відокремив період перебування в армії та на війні: армія не виправдала його очікувань (стала тим, що його гальмувало, а не розвивало): «...але це зовсім не той десант, який я собі уявляв. Жирні лизоблюди, що навмисне створюють тобі некомфортну ситуацію, а потім пропонують за хабар їі розрулити» [1, с. 126]; в той час, як на війні він себе почував «на своєму місці», потрібним, а свої дії корисними для суспільства.

Роман В. Ананьєва вирізняється серед інших документальних видань про війну на Сході України унікальним поєднанням текстового та графічного матеріалу (фото та відео 3 місця подій), що реалізовано завдяки QR-кодам, які вміщено у текст.

Війна для В. Ананьєва - особливий світ, в який він потрапив завдяки свідомому вибору, про який не шкодує. На війні він став сильнішим, зміг реалізувати свій потенціал, випробувати себе та свої сили. Світ війни В. Ананьєва - максимально деталізований, сконцентрований на передачі атмосфери та вражень від перебігу воєнних дій; об'ємний завдяки поєднанню текстового та графічного матеріалу, що підтверджує його безпосередню участь у бойових діях. 
У романі продемонстровано побут війни: «Вся моя зона комфорту звузилася до найпростіших потреб: попити, поїсти, попрати, помитися, поспати. При цьому я почувався чудово. Про дім навіть не думав» $[1$, c. 222]. Одним із комунікаційних намірів розповідача $\epsilon-$ відобразити атмосферу воєнної дійсності: «Ми встигли зробити пару кроків, як пролунав вибух, і мене відкинуло метри на чотири. Я розплющив очі, але все ще було темно. Страшний гул у вухах, перед очима в темряві мерехтять зірки...» [1, с. 237]. Хоча ми зауважили, що осмислення подій у романі «Сліди на дорозі» характеризується раціональністю, в творі присутні рефлексії розповідача як реакції на кульмінаційні моменти: «Чому так сталося? Все через нашу безпечність та недбалість. Одразу приїхавши на місце, ми мали б закопуватись якомога глибше, але все лінувалися, ходили на повний зріст по вершині пагорба, який проглядався за багато кілометрів» [1, с. 306]. Окремо розповідач загострив увагу на наслідках війни особисто для нього, та й для решти учасників бойових дій. Зокрема, ті, речі, що раніше викликали негативну реакцію, тепер - ігноруються; те, що раніше видавалося огидним, на війні - не викликає подібних реакцій: «...Відчув запах, який йшов від нього, і спіймав себе на думці, що більше цей запах не викликає у мене блювотного рефлексу...взагалі нічого не викликає» [1, с. 271]. В. Ананьєв репрезентував свій персональний досвід участі у бойових діях на Сході України: на війні - він не тільки відчув близькість смерті, але й те, що перебував на своєму місці, відчув себе потрібним та усвідомив важливість обраної місії.

Отже, фіксація та осмислення війни на Сході України авторамиучасниками подій характеризується: фокусуванням уваги на внутрішньому світі розповідача; суб'єктивністю та дискретністю пережитого й відображеного розповідачем досвіду участі у воєнних діях; репрезентацією авторських рефлексій та оцінок щодо перебування на війні; фрагментарним відтворенням подій, що значним чином вплинули на емоційний стан розповідача «тут і зараз», та моделюванням цих подій як персональної війни.

\section{Література:}

1. Ананьєв В. Сліди на дорозі. Київ : Наш формат, 2018. 275 с.

2. Іванова О. А., Червінчук А. О. Сучасна українська воєнна документалістика: автор та авторська стратегія. Scientific developments of European countries in the area of philological researches : Collective monograph. 2020. C. 221-237. URL: https://doi.org/10.30525/978-9934588-56-3.1.13

3. Коцюбинська М. Історія, оркестрована на людські голоси : екзистенційне значення художньої документалістики для сучасної української літератури. Київ, 2008. 70 с. 
4. Червінчук А. О. Наративність оповіді матеріалу в українській воєнній документалістиці (на прикладі книги «АД 242. Історія мужності, братерства і самопожертви»). Актуальні проблеми розвитку засобів масової комунікаиії в сучасній Украӥні: матеріали V всеукраїнської науково-практичної конференції для студентів та аспірантів, Вінниця, 21 квітня 2017 р. С. 46-47.

5. Червінчук А. О. Позиція автора у сучасній воєнній документалістиці (на прикладі книги Мартіна Бреста «Пехота»). Трансформація фінансової системи та обліку в умовах інновачійної глокалізації національної економіки. Секиія VII. Трансформація медіа-системи та розвиток масових комунікацій в умовах інформаційного суспільства: збірник наукових праць за матеріалами всеукраїнської науковопрактичної конференції, 25-26 жовтня 2018 р. Одеса, 2018. С. 261-262. 